\title{
Politics, Law, and Justice in People's Poland: The Fieldorf File
}

\author{
Agata Fijalkowski
}

Confessio est regina probationum.
(Confession is the queen of evidence.)

In 2012 the Polish press announced the excavations of an unmarked mass grave at Warsaw's military cemetery where resistance fighters from World War II were found to have been buried. ${ }^{1}$ The remains may include those of Brigadier General Emil August Fieldorf, who is considered by many to be a war hero and was sentenced to death in 1952. The subject of this article is the Fieldorf case and trial, which have rarely been discussed in English-language journalism or scholarship.

Judicial officials within or working intimately with the Soviet secret police made decisions affecting many lives in 1944-1956 in Poland. The era was defined by the way in which law was perverted to the detriment of defendants in show trials; in other words, the proceedings were conducted so as to make an impression on the audience, and there was a strong suggestion that the defendant's guilt was predetermined. ${ }^{2}$ Under Stalinist rule the Soviet model of law was extended to certain territories and eventually adopted by states like Poland. Stalinist justice was used against members of civil society, including both loyal followers and opponents, in equal measure, resulting in brutalities committed on a large scale. Eventually, control was gained over the populace's public and private lives, justifying the claim that Stalinist rule was totalitarian. ${ }^{3}$ In the current legal context, judicial officials who relied on illegal, premeditated, and culpable actions in violation of the law-as was the case in Poland in the period under discussion here-and whose decisions

The author is grateful to Bela Chatterjee, Michael Doupe, Andrzej Paczkowski, Norman Davies, Joanna Hanson, and the anonymous reviewers for Slavic Review for their invaluable feedback. Any errors are the author's own. Funding from Lancaster University's Faculty of Arts and Sciences Research and Development Fund facilitated research for this article. The author thanks the prosecutor's office, the research officers, and the Reading Room staff at the Chief Commission for the Prosecution of Crimes against the Polish Nation at the Polish Institute of National Remembrance (Instytut Pamięci Narodowej, hereafter IPN), Warsaw, Poland, for their assistance.

1. "W marcu kolejne prace eksumacyjne na wojskowych Powązkach,” RMF 24, 25 October 2012, at www.rmf24.pl/fakty/polska/news-w-marcu-kolejne-prace-ekshumacyjne -na-wojskowych-powazkach,nId,644349 (last accessed 30 September 2013). The investigation, led by the Polish Institute of National Remembrance, involves 117 victims of Stalinist justice.

2. George Hodos, Show Trials: Stalinist Purges in Eastern Europe (New York, 1987).

3. Though outside the scope of this paper, the topic of totalitarianism is a subject of debate. Jacek Kurczewski, for example, argues in The Resurrection of Rights in Poland (Oxford, 1993) that Stalinist rule was both totalitarian and authoritarian. 
resulted in wrongful execution, can be held criminally liable for committing a judicial crime (zbrodnia sadowa). ${ }^{4}$

Fieldorf, as brigadier general, played a critical role in the Polish Home Army (Armia Krajowa, hereafter AK), the underground force loyal to the Polish government-in-exile in London. The Fieldorf case is representative of the fate of the majority of Polish resistance fighters. Their cases were built on fabricated facts, falsified evidence, and confessions obtained under torture. Polish archival material confirms that these trials were adjudicated by judges who were carefully chosen in order to reach the desired result, which in most instances meant a capital sentence. ${ }^{5}$ While the focus of this article is Fieldorf, I argue that this Polish case study can be instructive when analyzing the ways in which the law was used as a political weapon in other states and regions with similar experiences of totalitarian rule. ${ }^{6}$

This article adopts a concentric structure, with the Fieldorf trial at the center. I begin by introducing Fieldorf, as understanding who he was will help us better appreciate the importance of revisiting his case. The discussion then turns to the school of thought that underpinned the rationale of the Soviet legal model and, critically, Stalinist justice. While there were many staged trials at this time in the Soviet Union, this article discusses the 1945 Trial of the Sixteen (Proces szesnastu), wherein the accused-the majority members of the underground Polish government-were comprised of Fieldorf's peers; this trial fundamentally destroyed any chance of having a legal Polish government in the country. Key staged trials were made public in order to present a façade of legality. They were also a means to gather intelligence about the opposition, especially during the trial's preparatory stages. The subject of the third section is the oft-neglected theme of legal education and the training of judges, which are critical to the application of law. This is followed by a discussion of the relevant law, central figures in the Fieldorf case, the trial proceedings, and then a brief consideration of key developments in the postStalinist period. The final sections examine the post-1989 Polish criminal investigation of the case within the context of judicial crimes.

Judicial crime introduces the necessary point of departure in these cases, as it provides an important framework within which to explore Stalinist justice in operation. A consideration of the trial proceedings provides a better understanding of the nature of Stalinist justice and the key issues that underlined the Fieldorf trial, namely its internal and external political contexts, its

4. The concept of judicial murder originally appeared in eighteenth-century German law. Voltaire used the term judicial assassins (assassins juridique).

5. The IPN file referred to in this article is from archival materials related to the Fieldorf trial as well as documentation amassed by Polish prosecutors in the post-1989 period. IPN BU 1769/8: Akta Głowne Prokuratora w sprawie zbrodnia popełnionych na szkodę Augusta Emila Fieldorfa (hereafter IPN BU 1769/8). See also S. Marat and J. Snopkiewicz, Zbrodnia, sprawa generała Fieldorfa-"Nila" (Warsaw, 1989), and Maria Fieldorf and Leszek Zachuta, Generał Fieldorf "Nil”: Fakty, dokumenty, relacje, 2nd ed., 2 vols. (Warsaw, 2006-07).

6. See, for example, Stéphane Courtois et al., eds., The Black Book of Communism: Crimes, Terror, Repression, trans. Jonathan Murphy and Mark Kramer (Cambridge, Mass., 1999), and Tony Judt, Postwar: A History of Europe since 1945 (London, 2007), 167. 
legal maneuverings, and the broader considerations surrounding the defendant through the eyes of his persecutors. One victim of Stalinist justice observed the following: "The whole indicates the part. The bar of history throws light on the trial in court. The court that testifies to the state of the world gives meaning to the testimony of the individual. And vice versa. The individual testimony enhances the picture of the court's procedure which prepares a certain settling of accounts with society. The legal trial allows the concealed mechanism of the historical trial to appear. The part reveals the inner structure of the whole."7

\section{August Emil Fieldorf}

Fieldorf was born in 1895 in Kraków in what was then the Austro-Hungarian empire. From an early age he exhibited a desire to serve in the army, and at the age of sixteen he signed up for training in shooting. Unsurprisingly, Fieldorf and his peers regarded Marshal Józef Piłsudski as their hero. The embodiment of Polish ideals, Piłsudski was born in Żułow (Zalavas), Lithuania, to a household with a strong sense of patriotism. His mark on Polish history is undeniable and was shaped by the hardened upbringing that influenced his rule (for better or worse) and those for whom he was a beacon of hope for the Polish cause, including Fieldorf and his contemporaries. ${ }^{8}$

This background formed the core of who Fieldorf was: a soldier at heart and loyal to the quest for Polish independence. Fieldorf joined the paramilitary Riflemen's Association in 1910 and then embarked on his military education at a school for non-commissioned officers. In 1914 Fieldorf volunteered for the newly established First Brigade of the Legions under Piłsudski, who believed that Polish independence would be won militarily; his legions waged war with Austro-Hungarian forces against the Russian army. Fieldorf fought on the eastern front and quickly advanced in his career to serve as secondin-command to an infantry platoon and later as a sergeant. In 1918 he joined the Kraków branch of the Polish Military Organization. Fieldorf remained on active duty and was eventually promoted to major and then battalion commander of the First Polish Infantry Regiment. In 1936 he was made lieutenant colonel. Soon after, Fieldorf served as commander of the Fifty-First Giuseppe Garibaldi Rifle Regiment within the Twelfth Infantry Division in eastern Poland (Kresy, the borderlands). With the outbreak of WWII, Fieldorf travelled to France for training before secretly reentering Poland to fight against the German occupation in covert missions. He was also promoted to full colonel and made the first emissary to the Polish government-in-exile. ${ }^{9}$ The Polish government-in-exile was formed in 1939, after the invasion by German and Russian forces. Through the underground Polish state and the AK it was able

7. Eugene Loebl, Sentenced and Tried: Stalinist Purges in Czechoslovakia, trans. Maurice Michael (London, 1969), 259. Emphasis in the original.

8. Norman Davies, God's Playground: A History of Poland, vol. 2, 1795 to the Present (New York, 1982), 159.

9. His nom de guerre comes from his route back into Poland, inter alia, over the Nile (Nil, in Polish). Fieldorf and Zachuta, Generat Fieldorf "Nil," 164. See also the film Generat Nil, directed by Ryszard Bugajski (Warsaw: Monolith Films, 2009), DVD. 
to exercise considerable influence in the country. Before the Warsaw Uprising, in 1944, he advanced to the position of brigadier general. By that time he was leading the activities of the special operations underground organization of the AK, Kierownictwo Dywersji (Kedyw). He also spent a period of time in a Siberian labor camp after being arrested in 1945 under the name of "Walenty Gdanicki." The Soviet authorities never knew who they were holding. He made his way back to Poland in 1947, but returned to a very different political situation.

Significantly, even by 1944 the Soviets were influencing the situation in a country they claimed to be liberating. In July 1944 the Soviets created the Provisional Polish Government of National Unity (Polski Komitet Wyzwolenia Narodowego, hereafter PKWN), an important step for Moscow in gaining control specifically over Polish territory. ${ }^{10}$ The communist authorities saw the Home Army soldiers and insurgents as "the spit-drenched dwarves of reaction" and enemies of the "people's homeland."11 Following liberation in 1945, the Soviets did not leave. There was no pressure from the western Allies to do so.

When Fieldorf returned to Poland in 1947, Soviet intelligence was keeping members of the Polish resistance under surveillance, and, in 1948, when Fieldorf and his wife settled in Łódź they joined the list of those who were being watched. The Main Office for Information of the Polish Army (Główny Zarzad Informacji Wojska Polskiego) was the military organ given regular reports from agents about Fieldorf and his whereabouts and activities. ${ }^{12}$ During this period, the secret police bided their time until Fieldorf could be detained. ${ }^{13}$ Fieldorf was eventually captured on 9 November 1950 and transferred to Warsaw, and shortly thereafter the interrogations began. Fieldorf found himself at the center of the newly developing legal system. ${ }^{14}$ Although he was treated as a criminal suspect, there was a delay, until November 21, before Fieldorf was formally arrested and detained on the order of the regional military court. The implication of this delay in formally charging Fieldorf became the focus of the Polish prosecution in the early 1990s when it reopened the Fieldorf file and related archival materials to confirm the identities of judicial officials involved in the case, including that of the military prosecutor

10. The PKWN was set up as a temporary executive organ in July 1944 by decree of the State National Council. Concerning the detention of the remaining leaders of the resistance, see Davies, God's Playground, 472, and R. F. Leslie, "The Years of Tempest, May 1943-December 1944," in R. F. Leslie, ed., History of Poland since 1863 (Cambridge, Eng., 1980), 282-83.

11. Grzegorz Jasinski and Pawel Ukielski, Guidebook to the Warsaw Rising Museum (Warsaw, 2007), 176. See also IPN 1769/1399.

12. Władysław Tkaczew, "Relacje między organami informacji a sądownictwem i prokuraturą w Wojsku Polskim w latach 1946-1947," in Witold Kulesza and Andrzej Rzepliński, Przestępstwa sędziów i prokuratorów w Polsce lat 1944-1956 (Warsaw, 2000), 389-411. See also Fieldorf and Zachuta, Generat Fieldorf "Nil," 425-85.

13. IPN 1796/1355.

14. In its early manifestations, Soviet law could not break free from the universal principles of criminal law, despite the adoption of progressive new terminology. See Vladimir Gsovski and Kazimierz Grzybowski, eds., Government, Law, and Courts in the Soviet Union and Eastern Europe, 2 vols. (London, 1959). 
who had signed the order, resulting in an investigation into whether she and her peers had committed a judicial crime in violation of the applicable law at that time. ${ }^{15}$

\section{The Soviet Model}

Iosif Stalin's prosecutor general, Andrei Vyshinskii, played a key role in shaping Soviet criminal law from the late 1920s. Vyshinskii held that "the will of the working people" was the source of power. The Communist Party, representing the will of the working class, was elevated above all state structures, including the legislature. Power was meant to be exerted to its full potential but within a strict structure in order to ensure maximum potential. Significantly, the Soviet prosecutor's position was modelled on Peter the Great's idea of a disciplinary "eye." The eighteenth-century apparatus operated independently as an institution that kept watch for the tsar in order to ensure the conformity to law of all governmental offices, including the courts. ${ }^{16}$ The model and its supervisory role were retained by the Soviet authorities in the postrevolutionary period.

According to Vladimir Lenin, judicial courts were really class courts and had to be told what was expected of them and what they were permitted to do. Vyshinskii further developed this theory and claimed that courts must follow party directives, and to do so effectively judges must be political activists. The court was not a part of the state administration per se; rather, it was called upon to decide appropriately, according to the objectives of socialist justice. ${ }^{17}$

This kind of legality proudly displayed itself as a new kind of egalitarianism, in which the state could justify violence through a process best described as "throttling," brought about by the masses themselves and linked to their education. The results of this process's implementation can be seen in relation to the so-called internal enemies of the state. ${ }^{18}$ In the words of one of the judges in the Fieldorf case, Fieldorf "had to be eliminated," as there was no chance of his rehabilitation. ${ }^{19}$ The implementation of such policies necessitated the secret police. ${ }^{20}$ Concerning the criminal law, the notion of guilt in criminal law was reworked to include guilt by association and collective responsibility. ${ }^{21}$ The legal objectives were politicized to suit the regime's revolutionary goals,

15. IPN 1796. See also Anne Applebaum, "The Three Lives of Helena Brus," Sunday Telegraph, 6 December 1998, reprinted at www.anneapplebaum.com/1998/12/06/thethree-lives-of-helena-brus/ (last accessed 14 November 2013), and Anne Applebaum, Iron Curtain: The Crushing of Eastern Europe, 1944-1956 (London, 2012).

16. William E. Butler, Soviet Law, 2nd ed. (London, 1988), 107.

17. Andrei Y. Vyshinsky, The Law of the Soviet State, trans. Hugh W. Babb (Westport, Conn., 1948), 503.

18. Kurczewski, Resurrection of Rights in Poland, 44-45.

19. This was stated by Maria Górowska, whose profile is discussed below. See also Lavinia Stan, ed., Transitional Justice in Eastern Europe and Former Soviet Union: Reckoning with the Communist Past (London, 2008), 93.

20. Timothy Snyder, Bloodlands: Europe between Hitler and Stalin (London, 2010), 73.

21. This was set out in the 1926 Soviet Criminal Code, which was amended in 1934. 
but at the same time this meant law and power would be synonymous: law became a political weapon that was used to keep the populace in check. ${ }^{22}$

\section{Trial of the Sixteen}

The underlying rationale of the Soviet staged trials was to uncover traitors and any other related challengers to the policy and "person of the General Secretary." ${ }^{23}$ The manner in which the trials were reported reveals the power of propaganda: "News ... was disseminated by clever whispering campaigns among the party membership. In their secrecy and with the silent disappearance of the accused, these were no less effective as instruments of terror than were the public trials." ${ }^{24}$ For the press and radio reports, the unmasking of the defendant held more significance than the verdict itself. ${ }^{25}$

By the time Fieldorf came to the attention of both Soviet and Polish intelligence in 1948, the ground had been established with the Trial of the Sixteen. This trial was held in Moscow 18-21 June 1945 and the accused were members of the AK who had initially been "invited" by General Ivan Serov to an "open meeting" on 6 March $1945 .{ }^{26}$ This was in fact a trap, and it resulted in the arrest and immediate transportation of the arrestees to Moscow. ${ }^{27}$ The trial proceedings show that the Soviet authorities had had the AK under surveillance for some time. ${ }^{28}$ The trial was held at the Military Collegium of the Supreme Court of the USSR. ${ }^{29}$ The defense offered on behalf of the accused was only nominal. After the prosecutor made his lengthy closing speech, with little tangible evidence to support the charges, most of the defense counsel remained silent or spoke only to agree with the prosecution. ${ }^{30}$ The trial coincided with a conference, which meant that there were international observers; western leaders, however, were advised to remain silent. It was a missed opportunity for the outside world to take a stand against the staged trials and against the kidnapping of non-nationals who were charged for alleged crimes committed on foreign soil. ${ }^{31}$ This latter aspect was a point raised by the Polish

22. Michael Voslensky, Nomenklatura: Anatomy of the Soviet Ruling Class, trans. Eric Mosbacher (London, 1983), 47.

23. Judt, Postwar, 177.

24. Hodos, Show Trials, xiii.

25. Judt, Postwar, 188.

26. Serov was acting commissar for External Affairs and head of Security Services in the Red Army on Polish territory. I am indebted to Andrzej Paczkowski for this information.

27. Several of "the sixteen" had been detained earlier in Majdanek.

28. Fieldorf was mentioned in the trial proceedings, along with the AK and its successor, the Niepodległość (NIE), which were considered illegal organizations engaged in subversive activities against Red Army detachments. See Moscow Trial of 16 Polish Diversionists June 18-21, 1945 (Moscow, 1945).

29. The chief prosecutor was Major General Nikolai Afanas'ev, the state councillor and chief prosecutor was Roman Rudenko (later chief prosecutor at the Nuremberg Trials), and the presiding judge was Colonel General Vasilii Ul'rikh, who was referred to as a "uniformed toad with watering eyes" by his peers. Anton Antonov-Ovseyenko, The Time of Stalin: Portrait of a Tyranny (New York, 1981), 83.

30. Ibid.

31. Norman Davies, Europe at War 1939-1945: No Simple Victory (London, 2007), 195. 
government-in-exile, which asked that the Polish defendants be tried before Polish courts. The request was refused but may have played a role in the sentences. ${ }^{32}$ It is also worth observing that three of the sixteen defendants were lawyers. ${ }^{33}$ As seen below, more often than not we find that Polish judicial officials were the target of draconian measures designed to eliminate members of the profession.

\section{The Polish Model}

The PKWN Manifesto of July 1944 is an essential component in any discussion about the nature of the Polish legal framework that was envisaged by the new authorities. Along with the March Constitution of 1921, the Polish Criminal Code and Code of Criminal Procedure from 1932 remained in force, with some revisions made to keep with communist ideology; however, the manifesto also declared the State National Council (Krajowa Rada Narodowa, hereafter KRN) the only legal source of power in Poland. ${ }^{34}$ The PKWN quickly began to promulgate decrees with respect to the competence of courts that would eliminate the judicial guarantees and protections associated with the basic tenets of judicial independence, such as the separation of powers. The discussion will limit itself to the key decrees issued by the PKWN and the Provisional Government of National Unity (Tymczasowy Rząd Jednośći Narodowej, hereafter TRJN) which concerned the judiciary and its reshaping along Soviet lines. ${ }^{35}$ These decrees were the most relevant normative acts of the Stalinist period. ${ }^{36}$

The decree of 31 August 1944 concerned the administration of punishment for, to use the language of the statute, "fascist-Hitlerite" criminals, those who had persecuted civilians and prisoners of war, and traitors of the Polish nation. The legal framework for these cases was set out a month later, in the decree of 12 September 1944, which concerned special criminal courts for Nazi collaborators. The provisions envisaged punishing not only these criminals but also traitors of the Polish nation (per Article 1), and they created a special section within each appellate court (specified in Article 2). ${ }^{37}$ These provisions

32. Some of the accused were acquitted; the rest received prison sentences of between four months and ten years. Further information as to the trial proceedings was released by the Russian authorities only in the 1990s. Fieldorf and Zachuta, Generat Fieldorf "Nil," 343.

33. See Marcin Zaborski, "Zarys ustroju i dziejów Adwokatury Polskiej," Palestra 11-12 (2012): 56-70.

34. The 1935 constitution was declared a fascist document by the Soviet authorities. See Andrzej Rzepliński, "Przystosowanie ustroju sądownictwa do potrzeb państwa totalitarnego w Polsce w latach 1944-1956,” in Kulesza and Rzepliński, eds., Przestępstwa sędziów i prokuratorów, 9-37.

35. The TRJN was a coalition government formed by the Polish communists and the Polish government-in-exile which was established by the KRN.

36. Adam Bosiacki, "Prawo stalinowskie i jego recepcja w Polsce 1944-1956-zarys problematyki,” in Kulesza and Rzepliński, eds., Przestępstwa sędziów i prokuratorów, 40-47.

37. Rzepliński, "Przystosowanie ustroju sądownictwa do potrzeb,” in Kulesza and Rzepliński, eds., Przestępstwa sędziów i prokuratorów, 17. 
in turn amended the 1932 Code of Criminal Procedure. The September 1944 decree also mentioned the qualifications needed on the part of judges appointed to the special section but did so only in general terms; thus, because the decree did not elaborate on any formal requirements, the appointed judge did not need to show any of the legal qualifications and experience normally needed to sit at the appellate level.

The decrees of 23 September 1944 and 30 October 1944 both concerned military courts. The latter decree was significant as it concerned the protection of state interests (ochronie Panstwa) and introduced a new category of offences, namely political crimes, which fell under the purview of the military courts (per Article 16); this effectively abolished the 1932 Polish Criminal Code and created the Military Criminal Code. The military courts' authority extended to all crimes concerning the protection of the Polish nation which could be found in decrees such as that of 23 September 1944. By expanding the authority of military crimes, the decree necessitated the creation of more military courts, which were subsequently provided for in the decree of 20 January 1946. In fact, the authorities ordered that the military courts be organized as Communist Party organs; their operation was closely monitored by the Soviets to ensure they worked "Soviet-style." 38

The decree of 13 June 1946 expanded the definition of political crimes by introducing the category of crimes threatening the structure and institutions of the state into the so-called Small Criminal Code (Mały kodeks karny). More important, this decree made possible the involvement of the secret police, in lieu of an investigative judge, in cases involving any of the offences outlined. The decree did little to clarify which organization was responsible for supervising the secret services. It is also important to note that the Small Criminal Code expanded the authority of the military courts to include civilians who were charged with crimes found in the decree. The code included further actions that could be penalized, such as disseminating propaganda against the alliance between Poland and the Soviet Union, as well as introducing more severe punishments for crimes that were created in the 1932 criminal code, such as making counterfeit money.

One of the most draconian TRJN decrees was the one from 22 January 1946 that introduced the Supreme People's Tribunal (Najwyższy Trybunał Narodowy), which had jurisdiction over war crimes and crimes against humanity (per Article 13(1)(1)), as well as crimes set out in the decree, including culpability for actions leading to the failure of Polish forces to defend the country against German troops in September 1939 (klęskę wrześniowa, the "September defeat") and facilitating fascism in the state (per Article 13(1)(2)). Later amendments made to the 1932 Code of Criminal Procedure in furtherance of Article 1 of the 20 July 1950 law changed the complexion of Articles 19 and 22(4) of the code by allowing for a broader interpretation of the notion of protecting state interests. ${ }^{39}$ In other words, ideological aims were being introduced into the prewar Polish criminal procedure law. This code was hailed in its day as a fine

38. Ibid., 20. The president of the Supreme Military Court worked with the minister of defense, together with an adviser whose function was fulfilled by a Soviet officer.

39. Dziennik Ustaw, no. 38 (1950), item 350. 
example of codification and clarity in terms of its guidelines. ${ }^{40}$ The draconian nature of the decree is confirmed by the penalty that the crimes carried: a capital sentence..$^{41}$

The January decree was clearer than the previous decisions with respect to legal qualifications. In furtherance of Article 1(1), the candidate only needed sufficient legal knowledge to be appointed to the bench, a requirement that was blatantly violated in the Fieldorf case, as will be discussed below. It is not clear whether more was expected of candidates to be appointed to a higher court. The relevant prewar statute concerning the structure of the common courts required judges on the Supreme Court to have at least nine years' judicial or prosecutorial experience or academic experience at the professorial level. ${ }^{42}$ From 1948 onward the minister of justice appointed judges to the Supreme Court who did not possess these qualifications, which, in theory, violated the law at the time. Moreover, the 1946 decree required the candidate to pledge an oath to undertake judicial duties faithfully. In reality, this was a display of political allegiance and a requirement that further ensured that Lenin's idea of courts as political agents was implemented in Poland.

Legal education was critical to what developed subsequently..$^{43}$ There were 7,980 practicing lawyers in prewar Poland. ${ }^{44}$ Of this total, 4,500, or 57 percent, were casualties of the war, while 1,110, or 21.5 percent, of judges, prosecutors, and judicial candidates (who had numbered 5,171), were listed as casualties. ${ }^{45} \mathrm{After}$ the zones under German occupation were liberated, approximately 3,500 judges and prosecutors who had worked during the interwar period reapplied for work in their profession. ${ }^{46}$ Many of the judges were educated in prewar Poland, and a large number had entered the profession prior to $1932 .{ }^{47}$ There was deep mistrust of the prewar judicial pool on the part of the authorities, who doubted their dedication to the new political and economic order. ${ }^{48}$ As a result, only 1,300 candidates were allowed to return to the profession. ${ }^{49}$ Likewise, some judges also expressed misgivings; at the end of 1946, 15 percent of judges expressed negative feelings toward the new regime, 70 percent felt loyal but expressed nostalgia for the prewar period, and 15 per-

40. Adam Lityński, "Na drodze ku nowej procedurze karnej: O postępowaniu przygotowawczym w latach 1943-1950,” in Kulesza and Rzepliński, eds., Przestępstwa sędziów i prokuratorów, 49-66.

41. Piotr Kładoczny, "Kara śmierci jako wykładnik polityki karnej państwa w latach 1944-1956,” in Kulesza and Rzepliński, eds., Przestępstwa sędziów i prokuratorów, 67-81.

42. Dziennik Ustaw, no. 5 (1930), item 43.

43. IPN 1769/1399. See Marcin Zaborski, "Szkolenie sędziów nowego typu w Polsce Ludowej, część 1,” Palestra 1-2 (1998): 79-92; Zaborski, “Szkolenie sędziów nowego typu w Polsce Ludowej, część 2,” Palestra 3-4 (1998): 105-10; Zaborski, "Szkolenie sędziów nowego typu w Polsce Ludowej, część 3,” Palestra 5-6 (1998): 131-51; and Zaborski, "Szkolenie sędziów nowego typu w Polsce Ludowej, część 4,” Palestra 7-8 (1998): 99-105.

44. Andrzej Rzepliński, Sądownictwo w Polsce Ludowej: Między dyspozycyjnością a niezawistością (Warsaw, 1989), 17.

45. Ibid.

46. Ibid.

47. Ibid., 18.

48. IPN 1796/1396-1397.

49. Ibid., 17. 
cent belonged to the Polish Worker's Party (Polska Partia Robotnicza). ${ }^{50}$ The reminiscences that judges expressed about the prewar period were viewed by the Polish authorities as dangerous. By then, in furtherance of the decrees issued between 22 January 1946 and April 1946, new law schools had been created, some of which provided an eight- to ten-month education program..$^{51}$ The first law school of this type was established in Łódż in 1946, followed by the Teodor Duracz Higher School of Law in Warsaw, which opened in 1948. The entire legal education system seemed to be geared toward controlling the minds of its practitioners rather than honing their analytical skills. ${ }^{52}$ By 1949 there were some 3,090 judges and prosecutors. By 1952, law graduates from the new schools comprised 31 percent (or 238 people) and university law graduates 58 percent (or 529 people) of those employed in the judicial system..$^{53}$ Andrzej Rzepliński aptly describes this period as the "war over the judiciary [walka o sadownictwo]." ${ }^{54}$ Certainly, the period critically exposed the judiciary's vulnerability following the implementation of key legislation. Additionally, many judicial officials had been casualties of war. Instead of looking for ways to strengthen judicial independence, the Soviet-backed authorities gained political control over the courts by changing their jurisdiction so as to minimize forms of external control over the executive branch. The reformed prosecutorial offices conformed to Soviet lines, although they never attained the status of their Soviet counterparts.

\section{The Judges}

In this section, I briefly present the biographies of three of the judges who adjudicated in the Fieldorf case at different stages. Igor Andrejew had his judicial application and exam waived when he was appointed deputy prosecutor on 28 February 1949. He applied to the appellate courts in Warsaw and did his internship at the Ministry of Justice in the capital. He was well aware of the requirements needed to be a part of the new legal framework, which included loyalty to the new objectives that underpinned the criminal law system in the form of protecting working-class interests.

Furthermore, Andrejew knew about the political nature of the cases he was adjudicating and that the Fieldorf case was one from which he could not recuse himself, as "my refusal [to hear the case] would have been a cowardly retreat." 55 In an interview with a journalist in 1990 Andrejew said that he thought Fieldorf was "some German," stating, "It is a shame, but this is what I

50. IPN 1796/1397.

51. These ten-month courses were established throughout the country until 1950. From 1951 to 1953 they were systematically closed. The duration of law studies then increased to fourteen months.

52. See Rzepliński, "Przystosowanie ustroju sądownictwa do potrzeb," in Kulesza and Rzepliński, eds., Przestępstwa sędziów i prokuratorów, and Zaborski, "Szkolenie sędziów nowego typu w Polsce Ludowej, część 1" and "Szkolenie sędziów nowego typu w Polsce Ludowej, część 2.”

53. Rzepliński, Sądownictwo w Polsce Ludowej, 19.

54. Ibid., 18.

55. In a letter to his daughter. IPN 1769/1405 and 1571. 
thought." ${ }^{56}$ The element of duress in Andrejew's having to adjudicate the case was most likely real, but his position is vague. He also indicated that he knew this was a case that had already been decided at the highest level. This decision came from the very top-from the Polish president, Bolesław Bierut, who was an NKVD agent before rising in the ranks of the party hierarchy.

During his career, Andrejew authored twenty-seven articles and monographs. His textbooks were required reading in criminal law study at all national law schools during communist rule. It was not until 1990 that his role in the Fieldorf case was revealed. In analyzing Andrejew's writings, a leading commentator on the subject has questioned the quality of Andrejew's legal scholarship in application to the case. Andrejew placed great importance on the function of the decrees at the time in identifying enemies of the state; however, from a legal positivist position it is doubtful whether Fieldorf could have committed a crime against "a Polish People's Republic" during a time of transition in which there was no official state. Yet, this was the legal viewpoint that Andrejew later championed in his writings in the post-Stalinist era. ${ }^{57}$

Not much is known about Emil Merz, another of the judges who adjudicated in the Fieldorf case, but his name appears frequently as a member of the bench in such cases. Merz was also a member of the secret police before being employed at one of the new law schools. Merz's professional experience was in the "secret sections" of the regional courts. It was there that the authorities quickly recognized his reliability, in particular with regards to political cases. According to a memo attached to the archival file, Polish prosecutors were informed that Merz died in 1972. It is unclear whether the personnel files of the former Ministry of Public Security, which might contain further information about Merz, have been accessed in the years since..$^{58}$ Merz was one of several members of the secret police to have been involved in the infamous secret courts. It is worth recalling that the definition of a judicial crime necessitates the crime's having been premeditated and then specific individuals having been selected to ensure its commission-it was only in the final stage that the case was presented to the administration of justice. In other words, these judicial crimes did not happen in isolation..$^{59}$

Maria Górowska (also referred to as "Maria Gurowska" in the archival materials) is arguably the most controversial of the three judges under discussion here. In addition to holding a deanship at several of the new law schools, she quickly rose from the position of judge to the rank of prosecutor and was then appointed to a delegation at the Polish Ministry of Justice. She remained a judge in the secret sections until they were dissolved in 1954. In fact, Górowska served as a judge until her retirement in 1970. Even the communist leadership was warned about her incompetence; at least one prosecutor from the Warsaw regional court identified her as a liability. A confidential letter

56. Z. Uniszewski, “Sędzia,” Tygodnik Solidarność, no. 7 (1990), and IPN 1796/1406.

57. IPN 1796/1395.

58. IPN 1769/1553.

59. Piotr Majer, "Aparat bezpieczeństwa publicznego a organy wymiaru sprawieliwości-elementy współpracy,” in Kulesza and Rzepliński, eds., Przestępstwa sędziów i prokuratorów, 475-84. 
was addressed to the first secretary of the Communist Party, Edward Ochab, in May 1956, two months after the Twentieth Party Congress, and described her as "having hardly any judicial experience"-a claim that demands further research..$^{60}$ Górowska worked as a judge until retirement, a length of service that would have been notable to her colleagues and peers given this apparent incompetence. Her political loyalty and manipulability was rewarded by the Polish authorities; anywhere else, the relevant legal professional body would have moved to dismiss her and bar her from the profession. The effect of the decrees was far reaching, permitting unqualified individuals to enter the profession and repaying pliability with job security.

\section{The Fieldorf Trial}

Fieldorf's interrogation lasted from November 1950 to March 1951 and focused on obtaining evidence of anti-state activity, as outlined by the Investigative Department of the Ministry of Public Security ${ }^{61}$ The investigation was conducted by military intelligence officers, in cooperation with the judiciary and prosecution. In May 1951 his detention was extended, and in July 1951 the interrogation of the witnesses began; at that point the case was forwarded to the prosecutor general. Fieldorf consistently denied the charges and protected his colleagues during questioning; any incriminating information he provided to the interrogators was in reference to persons who were no longer alive. ${ }^{62}$ Coercive measures were used in interrogating witnesses to ensure that their testimonies would fit the case being built against Fieldorf, which started by identifying anti-state activity in the 1920s during the Polish-Soviet War. ${ }^{63}$ The prosecutor general, after examining the case file, initiated trial proceedings based on charges alleging that Fieldorf had violated Article 1(1) of the $31 \mathrm{Au}-$ gust 1944 decree, despite the fact that not all the information sought by the investigation team had been found. ${ }^{64}$ Shortly after this, the general prosecutor wrote a secret memo to the District Court of Warsaw; in other words, the case was handed over to the secret section. As noted above, key decrees provided for the introduction of secret courts within the common court system. Evidence from the relevant archival materials (not all of which are available at this time) tells us that secret sections were created at the district court (or

60. Henryk Cieśluk, IPN 1796/1414. Rzepliński also notes claims about the incompetence of the military courts established by the Soviets, which were comprised mainly of Soviet officials; the operation of these courts came under the control of the Supreme Court and the Supreme Military Court. Rzepliński, Sadownictwo w Polsce Ludowej, 19. Regarding the appointment of potentially unqualified judicial officials, Edward Ochab said, "It was a difficult period in the life of our nation, but, viewed as a whole, it was the greatest turning point in our country’s history.” Quoted in Teresa Torańska, “Them”: Stalin's Polish Puppets, trans. Agnieszka Kołakowska (New York, 1987), 39.

61. Fieldorf and Zachuta, Generat Fieldorf "Nil," 490. The interrogation was led by Kazimierz Górski, who was the subject of criminal investigation in the prosecution's case in 1990.

62. Ibid.

63. Fieldorf and Zachuta, Generat Fieldorf "Nil," 541.

64. Ibid. 
court of first instance), the regional court (court of second instance), the appellate court, and the Supreme Court. 65

The interrogations did not cease. As one survivor noted, "Paradoxical as it may sound, completion of the final set of questions and answers was a joyful occasion for the prisoner, for it meant that his detention for interrogation with its 'hard treatment' was almost over." 66 The Fieldorf trial proceedings were held at the district court in Warsaw on 16 April 1952. The trial began at 12:30 p.m. Maria Górowska was presiding judge, along with two lay assessors.$^{67}$ Fieldorf's plea of not guilty was recorded. The court referred to evidence indicating Fieldorf's anti-state activities and to the number of casualties1,026-connecting these deaths to instructions issued by Fieldorf to those under his command during the occupation of Poland by German forces. ${ }^{68}$ To make such an argument the prosecution had to prove the chain of command, showing that the organization of the AK was a hierarchy in which Fieldorf had played a key role. ${ }^{69}$ The link was tenuous, but there was no possibility of challenging it. In fact, the AK archives seized by the Soviet authorities held within them documentation that included an order from March 1943 forbidding any action against partisan groups or the Red Army; this material was never investigated. ${ }^{70}$ True to the Soviet model, to quote a popular thriller set in the Stalinist period, "the duty of the investigator was to scratch away at innocence until guilt was uncovered. If no guilt was uncovered then they hadn't scratched deep enough." ${ }^{.11}$ An investigation would never be permitted, as the entire case was scripted from start to finish, and any statement by Fieldorf or the witnesses was carefully censored to support the hard evidence that was already in place.

All questions during the interrogation centered on Fieldorf's activities within the AK: when he joined, what his responsibilities were, and whose orders he followed. ${ }^{72}$ The witnesses were brought into court and confined to a separate room. The court heard the witnesses' testimonies individually and without a court oath. One witness, Tadeusz Grzmielewski (known by the pseudonym "Igor"), a top commander in the AK alongside Fieldorf, stated in his original testimony that he had seen Fieldorf give the order to liquidate Soviet partisans; he later indicated in court that he never saw such an order given. The court concluded that the witness's original testimony was true. The second witness, Władysław Liniarski (known by the pseudonyms "Mścisław," "Jur," and "Jan"), was another key commander in the AK alongside Fieldorf; he confirmed that he also knew about the orders and instructions. At the trial

65. Ibid., 547-48.

66. Loebl, Sentenced and Tried, 47.

67. Lay assessors were also selected according to their political manipulability.

68. IPN 1796/1355.

69. The court made no effort to learn more about the organization of the AK in order to gain more information about alleged orders to kill targets. IPN 1796/1397.

70. IPN 1796/1397, Sr 294/51 in the Kedyw archive; the evidence was most likely withheld by the Ministry of Public Security. IPN 1418.

71. Tom Rob Smith, Child 44 (London, 1997), 45.

72. IPN 1796/1397, and Fieldorf and Zachuta, Generat Fieldorf "Nil," 496. 
he was not clear in his testimony about whether he knew that the instructions came from Fieldorf. Liniarski was brought in on a stretcher, barely conscious; Fieldorf did not recognize the broken figure, whose injuries were the result of special interrogation techniques introduced by Soviet advisers sent by Stalin's notorious chief of the Soviet security and secret police apparatus, Lavrentii Beriia. ${ }^{73}$ Despite the state of this witness's health, the court satisfied itself that the witnesses had confirmed the evidence of anti-state activities, and no further clarification was requested in connection with the accused. The court also refused to seek clarification as to the hierarchy, activities, and territorial actions of the AK faction under Fieldorf's command. ${ }^{74}$ The court further declined to hear two key witnesses, including Jerzy Mering, Fieldorf's stateappointed defence counsel. It held that the prosecution's case was clearly concluded on the evidence. Fieldorf was found guilty and sentenced to death. The court disregarded the criminal procedure law in force at that time, from the 1932 code, relating to the introduction of evidence and the cross-examination of witnesses. The proceedings were concluded at 20:30 p.m., having lasted eight hours-a full day's work.

From this moment, there was no real chance of appeal, but one was filed, in writing, by Fieldorf on 27 May 1952. The Regional Court of Warsaw (the court of second instance) heard the appeal; it was a secret section and Merz presided over the case. The regional court upheld the district court's decision. Even though evidence was supplied by Fieldorf to dispute the facts, accompanied by a request to call witnesses, the court replied that this evidence had no bearing on the case against the general. In fact, even if the territorial actions of the AK faction had reached excessive levels, these respective sections were responsible to the given group and command of the AK, and not directly to Fieldorf. There is no evidence of any such orders coming from Fieldorf, as the archival material confirms. ${ }^{75}$

On 20 October 1952 the Supreme Court heard the appeal, with Merz presiding and Andrejew one of the judges, along with Gustaw Auscaler and Paula Kern representing the prosecution. ${ }^{76}$ The appeal alleged that the Warsaw district court's verdict was unjust, as it was based on political orders. ${ }^{77}$ Fieldorf also asked that eight witnesses be heard, holding that the court of first instance had made procedural and factual mistakes, and requested that the decision be overturned and the case returned to the regional court. Fieldorf's appeal indicated that none of the orders presented in this case satisfied the August 1944 decree, which required that the perpetrator act with the full knowledge that they were collaborating with the German authorities and that the killings be done on a mass scale; these were the conditions outlined in Article 1(1) of the decree. None of the criteria was satisfied in this case. Fieldorf asked that

73. IPN 1796/1397. See Fieldorf and Zachuta, Generat Fieldorf "Nil," 561n9.

74. IPN 1796/1397 and Fieldorf and Zachuta, Generat Fieldorf "Nil," 496. According to the court notes, at the trial Liniarski did not know if the instructions came from Kedyw. The court refused clarification as to Kedyw hierarchy, activities, and territorial action. IPN 1796/1397.

75. IPN 1796/1402.

76. IPN 1796. See also Fieldorf and Zachuta, Generat Fieldorf "Nil."

77. Fieldorf and Zachuta, Generat Fieldorf "Nil,” 575. 
the court consider the context of the territory under dual occupation. The AK itself did not have full and complete information and did not know who was in charge of the respective AK sections that were carrying out operations in various territories during the war. Such information was not known to Fieldorf, nor was it within his purview. Once again the court refused to clarify the hierarchy and structure of the organization. The court notably ignored Article 337 of the 1932 Code of Criminal Procedure regarding witnesses. The court, following the district court's reasoning, did nothing to establish the facts, and as a result the general's appeal failed.

Fieldorf's family wrote to President Bierut in October 1952 asking for the general's pardon, referring to him as a man who "responded in a positive way to the People's Poland immediately, as he also comes from the people.... He should not be judged so harshly that his life is taken away."78 Concerning the pardon, the district court sat on 8 December 1952, with Górowska presiding, and held that Fieldorf did not deserve a pardon. ${ }^{79}$ This decision was upheld by the Supreme Court, also with its original bench of Merz, Auscaler, Andrejew, and Kern, on 12 December 1952. In December 1952 the defense counselor Mieczysław Maślanko, also appointed by the state, wrote to the Council of State (Rada Państwa) with a request for a pardon, on the grounds that Fieldorf could never have given the orders but only cooperated with the commanders who did so. ${ }^{80}$ Fieldorf himself never asked for a pardon, nor did the Council of State grant one. A letter sent under the cover of state secret by the prosecutorial branch dealing with pardons informed the Warsaw district court that the Council of State refused to do so. ${ }^{81}$ On 17 February 1953 Alicja Graff from Department III of the General Prosecution Office, which controlled the operations of the secret sections, wrote to the head of Prison Services requesting that Fieldorf's execution be performed in an expedient manner. The death sentence was carried out on February 24. The site of the grave was unknown until 2012.

Andrzej Paczkowski notes that it is still not certain who gave the order to arrest Fieldorf and try him in a secret section. ${ }^{82}$ The decision making most likely included Bolesław Bierut, Jakub Berman, Hilary Minc, and Stanisław Radkiewicz-this much is confirmed by Andrejew in a letter to Fieldorf's daughter-but there is no certainty as to the capacity in which each acted. ${ }^{83}$ Bierut, Berman, Minc, and Radkiewicz belonged to the Committee of the Political Bureau for Public Security (Komisja Biura Politycznego ds. Bezpieczeństwa

78. Ibid., 595. Fieldorf's father also appealed to Bierut.

79. Fieldorf and Zachuta, Generat Fieldorf "Nil," 600.

80. Ibid. According to Andrejew, Mieczysław Maślanko did not dispute the evidence against Fieldorf. Fieldorf and Zachuta, Generat Fieldorf "Nil," 644. Maślanko testified before the Ministry of Justice commission (discussed below) that the Fieldorf case was a continuation of the Trial of the Sixteen. See ibid., 691.

81. Ibid.

82. Andrzej Paczkowski, personal correspondence, 2 September 2012.

83. Fieldorf and Zachuta, Generat Fieldorf "Nil," 641. Jakub Berman, a product of prewar legal education, was in charge of the Polish secret police (Urząd Bezpieczeństwa) from 1944 to 1953, Hilary Minc was responsible for economic affairs from 1944 to 1956, and Stanislaw Radkiewicz was head of the Polish secret police from 1944 to 1954. See Torańska, Them. See also Fieldorf and Zachuta, Generat Fieldorf "Nil," 575. 
Publicznego), which decided on all important activities concerning the prosecution and judiciary.

In his last letter from prison, Fieldorf wrote to his wife, "Please do not worry about me, this will not bring you any relief, nor will it help." ${ }^{84}$ The family underwent a double trauma: losing their loved one in secret proceedings and then being denied the truth about his death, owing to the distortion of historical facts by both the Soviet and Polish communist authorities. As Rzepliński notes, the court had procedural obligations and should have had ample opportunity to learn the true facts of the case. All three judges had the legal knowledge necessary to establish that the evidence against Fieldorf was questionable-the reports used by the prosecution as evidence were hand written. It is worth noting that some 139 cases of the same type against members of the AK were heard in $1952 .{ }^{85}$ In fact, cases were heard alternately by Merz and Górowska, and in most instances the death sentence was imposed. ${ }^{86}$

Both Andrejew and Górowska defended their role and participation in the Fieldorf case to varying degrees. For Górowska, it was clear that the case concerned an enemy of the state, and she as a judge had no doubt as to his guilt. If she had any regrets, it was that she "had one foot in the grave," and she lamented the fact that the Ministry of Justice was reopening the matter ${ }^{87}$ Andrejew died in 1994. Górowska died in 1998, before her trial, adding to the frustration that the AK veterans felt about the whole process of addressing past abuses.

\section{The Post-Stalinist Period}

In November 1956 the minister of justice called together a commission in Warsaw to investigate the activities of the secret section within the Supreme Court, appellate court, and regional courts in Warsaw. The Khrushchev era heralded a period of seeming transparency as part of an effort to instill some semblance of socialist legality into the system and public consciousness. However, any effort to determine accountability led to a dead end. The members of this commission found that these secret sections were created in 1950 at the instigation of the vice minister of the secret police, together with key military officials. ${ }^{88}$ The commission found a plethora of legal violations in these cases; in one, for

84. Quoted in Fieldorf and Zachuta, Generat Fieldorf "Nil," 602.

85. IPN 1796/1418.

86. Ibid.

87. IPN 1796/1402.

88. The secret sections were organized by the director of the Special Department of Judicial Supervision and the director of the Special Department of the Supervision of the Prosecution. The commission discovered that from 1950 to 1954 the secret section heard 506 cases and examined 114 proceedings. Names of judges appeared repeatedly in the archive files, all of whom were from the Ministry of Justice. The mastermind of the courts' construction, as well as the supervisor of the proceedings and caseload, was the president of the regional court in Warsaw, Ilia Rubinow. IPN 1976/1361. See also Maria Stanowska and Adam Strzembosz, Sędziowie warszawscy w czasie próby 1981-1988 (Warsaw, 2005), $25-41$. 
example, the court sentenced the defendant to death without hearing testimony from any of the twenty witnesses. The commission did nothing to hold these judicial officials accountable for behavior that was deemed unusual in the general political circumstances of the period 1950-1954. The Fieldorf family's request for further details about the case was never answered, and internal investigations were discontinued by the public prosecutor in $1958 .{ }^{89}$ In July 1960 compensation was awarded to Fieldorf's wife for the wrongful conviction rendered by the District Court of Warsaw on 16 April $1952 .{ }^{90}$ The compensation was not the rehabilitation of his name, but it was more symbolic: the ruling referred to the illegal means by which the evidence on which the court in the Fieldorf case based its decision was gathered-there was no assignment of guilt to any specific judicial official. Helena Wolińska-Brus, the military prosecutor who signed Fieldorf's detention order, which is discussed below, was forcibly retired in $1955 .{ }^{91}$

The post-Stalinist period was marked by factional fighting within the Communist Party and provided an opportunity for Polish communists to oust from the government ranks Stalinist-backed appointees in order to forge a path that was still communist but less Soviet driven. Forced retirement, as seen above, was imposed on key figures in an effort to move them into nonpolitical positions, as was the case with Berman, who "spent an enjoyable second career editing encyclopaedias." ${ }^{2}$

In the context of the Cold War, these events were not a high-priority subject for international pressure in comparison with the significance that weapons and economic superiority would carry. The declaration of a general amnesty following Stalin's death and the subsequent Twentieth Party Congress in 1956 removed the possibility of transparency and accountability. ${ }^{93}$ "Organised injustice" typified the post-1956 period. ${ }^{94}$ The end of Stalinist rule meant a return to a notion of legality that was "by no means less dictatorial but of a much less exuberant variety." 95 Poland was unique in eastern Europe in that it did not hold staged trials of its communist leaders, although several,

89. In fact, Władysław Liniarski was questioned about the Fieldorf case in 1957 before the district court, where he withdrew his testimony because it had been given under torture.

90. Fieldorf and Zachuta, Generat Fieldorf “Nil,” 633.

91. I am grateful to Norman Davies for this information. Personal correspondence, 29 August 2013.

92. Norman Davies, “The Deep Stains of Dictatorship,” review of The Taste of Ashes: The Afterlife of Totalitarianism in Eastern Europe, by Marci Shore, New York Review of Books, 9 May 2013, at www.nybooks.com/articles/archives/2013/may/09/deep-stains -dictatorship/?pagination=false (last accessed 14 November 2013). Davies, personal correspondence, 29 August 2013.

93. Andrzej Friszke, “Epilogue: Polish Communism in Contemporary Debates,” in Anthony Kemp-Welch, ed. and trans., Stalinism in Poland, 1944-1956: Selected Papers from the Fifth World Congress of Central and East European Studies, Warsaw, 1995 (New York, 1999), 149-52.

94. Kurczewski, Resurrection of Rights in Poland, 67-99.

95. Kurczewski, Resurrection of Rights in Poland, 72. See also Kemp-Welch, ed. and trans., Stalinism in Poland, 1944-1956. 
including Władysław Gomułka, were held under house arrest. It is reasonable to assume that these leaders would have been tried had Stalin lived longer.

\section{Post-1989}

In 1989 Fieldorf was rehabilitated by the Sejm, the lower house of the Polish parliament. In 1990 the Polish prosecution turned to two leading criminal law professors, Andrzej Rzepliński and Andrzej Gaberle, for expert opinions before initiating a criminal investigation against the judicial officials involved in the Fieldorf case. ${ }^{96}$ For Rzeplinski, the answer to the question of whether the judicial officials were criminally liable could be found in the archives. He relied on their personal files, the protocols of the Ministry of Justice in the period 1949-1953, former President Bierut's files on the judiciary, and the Ministry of Justice archives. Many of these files had been closed until this criminal investigation began.

The starting point for Rzeplinski in the Fieldorf case was the underlying Soviet-based philosophy of the secret sections, which, in Rzepliński's view, "mask[ed] the falsehood that courts are apolitical and anti-class."97 The Soviet courts had played an active role in building the structure of the Polish state, a project motivated by eliminating class enemies. As such, there was no chance of an independent judiciary. The declaration in the 1944 PKWN Manifesto that the legal basis of the judiciary is dictated by the state of law before 1 September 1944 (in other words, the principles outlined in the 1921 constitution) was a lie, a claim that was ignored by the authorities, and another example of bad legal practice that was adopted or copied from the Soviets. By 1945, judges were prohibited from affiliating themselves with any political party or activities that would undermine their loyalty to the new Polish state. Rzeplinski pointed out that none of the judges on the 1952 panel were actually appointed to the bench tout court as provided for in law. ${ }^{98}$ Rzepliński's case outlined how the law was used to undermine one of the basic legal principles, a fair trial, which was denied to the accused by the court's refusal to allow the state's evidence to be challenged. ${ }^{99}$

Where Rzepliński provided the key contextual factors, Gaberle set out the relevant legal, procedural issues. For Gaberle, a professor of criminal law and procedure, the Fieldorf case needed to be examined as a classic example of judges permitting a judicial crime to take place, evidenced by illegal, premeditated, and culpable actions in violation of Article 225(1) of the 1932 Pol-

96. Andrzej Gaberle passed away in February 2012.

97. IPN 1796/1395.

98. IPN 1796/1401. In other words, not all the judges were qualified to sit on the bench of the Supreme Court. Merz, for example, was appointed on an annual basis. Rzepliński, "Przystosowanie ustroju sądownictwa do potrzeb," in Kulesza and Rzepliński, eds., Przestępstwa sędziów i prokuratorów, 27.

99. Gorowska wrote a final political testament that was sent to the prosecution upon her death in 1998. In it she notes that the AK was a criminal organization. She based her claims on the evidence that was provided by the witnesses. The reasons for the poor state of health of the two key witnesses would have been known to her. IPN 1796/1363. 
ish Criminal Code-in effect, a case of premeditated murder. ${ }^{100}$ In Gaberle's view, Fieldorf could not have been found guilty under the decree in question because the necessary criteria were simply not met. Based on this, the prosecution's case was illegal from the start. At each question concerning the evidence, the relevant judicial organs broke fundamental principles of criminal law and violated the principle of objectivity, as set out in Article 9 of the 1932 Code of Criminal Procedure. Gaberle also confirmed that the judges in the case should have known about the relevant procedural law. In his view, judicial activity could be illegal on grounds other than corruption and deceit. Gaberle advocated a wider approach to this question, suggesting that a judge who premeditatedly breaks the law for political reasons using false evidence is criminally liable for reaching the invalid verdict. There are further implications where a death sentence is imposed and where the court ignores procedure when considering a death sentence. Finally, the fact that Fieldorf did not qualify for a pardon on political grounds, in addition to the court's opinion that he had no hope of being resocialized was, for Professor Gaberle, a clear example of cynicism. ${ }^{101}$

Some of the judicial officials involved in the secret sections, such as Andrejew and Auscaler, became prominent members of the criminal law community in the post-Stalinist period. Rzeplinski argued that, as directors of the newly formed law schools, judicial officials who adjudicated in cases that saw miscarriages of justice in the period 1944-1956 were responsible for the results of these unjust cases. ${ }^{102}$ It is worth recalling that a number of the judicial officials serving the new regime were products of a prewar legal education. ${ }^{103}$

In terms of legal definitions, the notion of judicial crime is not necessarily peculiar to Poland. The concept of judicial crime arose during the Nuremberg Trials, though no specific charges were laid at that time. ${ }^{104}$ Legal scholarship refers to the notion of perverting the course of justice (Rechtsbeugung), which is motivated by personal benefit and results in harm to the defendant. ${ }^{105}$ If the result is a wrongful execution, then a separate notion of judicial crime might arise but be challenged by the principle of legality (Rechtmäßigkeit), whereby establishing intention is difficult when a judicial official has merely applied the law. In the mid-1990s the German Federal Supreme Court addressed the definition of judicial crime following a series of cases concerning the draconian sentences rendered by judicial officials in the former East Germany. ${ }^{106}$

100. IPN 1796/1460.

101. IPN 1796/1472.

102. IPN 17961401.

103. See Zaborski, “Zarys ustroju i dziejów Adwokatury Polskiej,” and Rzepliński, "Przystosowanie ustroju sądownictwa do potrzeb," in Kulesza and Rzepliński, eds., Przestępstwa sędziów i prokuratorów.

104. See Witold Kulesza, "Odpowiedzialność karna sędziów i prokuratorów za zbrodnię sądową,” in Kulesza and Rzepliński, eds., Przestępstwa sędziów i prokuratorów, 507-15.

105. The notion of perverting the course of justice is not found in Polish criminal law.

106. See Kulesza, “Odpowiedzialność karna sędziów i prokuratorów,” in Kulesza and Rzepliński, eds., Przestępstwa sędziów i prokuratorów, and Ryszard W. Piotrowicz and 
The notion is key to the context of the secret sections of the Stalinist period but also not specific to them, as it extends to decisions rendered in all common courts, including military courts. ${ }^{107}$ In the Polish context, the notion of judicial crime can be set out in several key categories:

A judicial crime is committed if the judge is guided by provisions broadly construed to allow for a finding of guilt, usually in order to imprison or execute the defendant, who is viewed as a threat to the regime. An example of this is found in Article 1 of the 30 October 1944 decree concerning the protection of state interests. ${ }^{108}$

A judicial crime is committed when the judge, in sentencing, finds guilt by analogy. An example is found in Article 7 of the 1946 decree concerning crimes specific to the construction of the state. In one case, from 1949, a court rendered a death sentence against an individual who had spent the war in a labor camp in German-occupied Poland; the implication was that he chose to be in Germany. ${ }^{109}$

A judicial crime is committed when the sentence is based on a process that violates the defendant's basic civil liberties, including, inter alia, brutal interrogation and denial of access to legal advice or defense. These are fittingly described as "toilet" or "loo" courts (procesach kiblowych). ${ }^{110}$

A judicial crime is committed when the punishment exceeds the severity of the crime. In one case a death sentence was given to a 16-year-old who lived on a farm in German-occupied Poland for possessing a firearm that was never used. ${ }^{111}$

A judicial crime is committed when the case is based on fabricated facts, gathered in a secret and nontransparent fashion, wherein evidence that is never verified is treated as the basis of the charges. The underlying motive is to undermine the defendant's expressed loyalty to Poland. ${ }^{112}$

As the 1932 Code of Criminal Procedure was never abolished by the authorities, it is equally important to draw attention to the key provisions of the code. For example, Article 54 requires the court to administer justice fairly and take into account both subjective and objective considerations affecting the offender in relation to determining responsibility for the crime. Article 92 requires the judge to adhere to the principles of legal certainty and the law. In

Sam K. N. Blay, eds., The Unification of Germany in International and Domestic Law (Amsterdam, 1997), 162-69.

107. A key feature of the decisions is their length, usually half a page of typewritten notes relating to the charges, decision, sentence, and signatures, usually countersigned by Bierut. Kulesza, “Odpowiedzialność karna sędziów i prokuratorów," in Kulesza and Rzepliński, eds., Przestępstwa sędziów i prokuratorów, 509.

108. The article states, "Whoever enters into an association that is designed to overthrow the democratic system of the Polish state, or engages, participates, directs, or provides it with weapons or assistance, will be punished by imprisonment or capital sentence."

109. Kulesza, “Odpowiedzialność karna sędziów i prokuratorów,” in Kulesza and Rzepliński, eds., Przestępstwa sędziów i prokuratorów, 511.

110. Ibid.

111. Ibid.

112. Ibid. 
the Fieldorf case and related trials, these provisions were blatantly ignored to meet the aims of a policy that made the criminal law a political weapon.

Further to the above examples, it is important to note that the authority for judicial crime is currently found in Article 4(1a) of the 1998 law concerning the Institute of National Remembrance. ${ }^{113}$ The statute of limitations period is in play, beginning 1 August 1990 and running for forty years for acts of homicide (thirty years for other communist crimes). ${ }^{114}$ Crimes that are recognized by international law as crimes against humanity, crimes against peace, and war crimes are not affected by the statute of limitations in Poland, nor are they affected by the former amnesty or abolition decrees issued in communist Poland before 7 December 1989 (see Article 4(1) of 1998 law). Some of the judicial crimes committed by officials during the 1944-1956 period in Poland are considered crimes against humanity: namely, the wide practice of atrocities tolerated or condoned by a government or de facto authority. ${ }^{115}$

In this context, the criminal prosecution of judicial officials for communist crimes in the Fieldorf case became a legal possibility and was supported by those victims who formed the community of surviving members and family and friends of the AK. The investigation itself was formally initiated on 5 May 1992 against all officials involved in carrying out judicial crimes against Fieldorf between 9 November 1950 and 24 February 1953 in Warsaw. Several of these officials had emigrated from Poland in the 1950s and died in their newly adopted countries of residence. ${ }^{116}$ The case established against the military prosecutor, Helena Wolińska-Brus, who had authorized Fieldorf's detention, featured more prominently in the media than those against her colleagues. Residing in Great Britain by the time of the investigation, Wolińska-Brus was vehement in her refusal to return to Poland to answer questions related to the case. ${ }^{117}$ For a while the momentum stayed with the Polish prosecution, but parliamentary debates about clarity in Polish law with respect to the statute of limitations for communist crimes affected the pace of the investigation. ${ }^{118}$

113. Dziennik Ustaw, no. 155 (1998), item 1016. "The Act on the Institute of National Remembrance,” 18 December 1998, at ipn.gov.pl/portal/en/31/327/The_Act_on_the_ Institute_of_National_Remembrance.html (last accessed 15 November 2013).

114. Note that the 30 November 2006 amendment to the 1998 law, in force from 15 March 2007, extended these statutory limitation periods.

115. Defined in Article 6(c) of the 1945 Charter of the International Military Tribunal of Numemberg, 82 UNTS 279, and Article 7 of the 1998 Rome Statute of the International Criminal Court.

116. Merz was one such official. See IPN 1769/1553.

117. Wolinnska-Brus called Poland "a despicable country" in which she saw the investigation of her involvement in the Fieldorf case as a witch hunt that was "vengeful" and "anti-Semitic." See IPN Sygnatura (Sygn.) Akt PO. Sledztwo (Sl.) 6/97: Bezprawnego pozbawienia wolnosci Augusta Fieldorfa pzrez prokuratura Naczelnej Prokuratury Wojskowej pplk Helene Wolinska p-ko pplk. w st. spocz. Helena Wolinska-Brus c. Jana art. $248 \& 2 k k w$ zw. Art. 2 a i 2 b ust. zdn. 06.04.84r. Gl. Kom.Bad.Zbr. p-ko Nar. Polskiemu, K-1-225. See also Applebaum, "The Three Lives of Helena Brus."

118. Retroactivity of a law may not have been expressly provided for in the constitution at the time, but it quickly became one of the fundamental components of the rule of law, as interpreted by the Constitutional Tribunal in judgments K 5/90, 40; K 7/90, 50-51. Jorg Arnold and Ewa Weigend, "Prawo karne, zmiana systemu politycznego i obrachunek 
Wolińska-Brus argued that she was not involved in the interrogations or subsequent proceedings in the Fieldorf case and questioned the legal basis of the charges against her. ${ }^{119}$ In the end, the British authorities saw a possible violation of retrospective justice when they noted a different period of statute limitation on the offence that was originally time barred. Extradition was refused in 2006 on two more grounds. First, the state of Wolińska-Brus's health, given the fact that the events under investigation had taken place over fifty years prior, made it questionable whether these offences were extraditionworthy crimes, rather than political offences that were exempt from extradition. Second, it was considered oppressive to continue to ask for extradition. The final refusal was exercised by the Home Secretary. ${ }^{120}$ Applebaum notes, "[This] isn't an Anglo-Saxon debate. ... The exploration of a totalitarian past isn't a British passion."121 Wolińska-Brus died in 2008.

Finding evidence from a variety of archives, locating witnesses, and establishing a case on charges of a judicial crime might have underpinned the piecemeal pace of the entire investigation, but the passage of time itself and the death of the key perpetrators would prove to be an insurmountable challenge. In the end, it is not clear whether the charge of judicial crime would have succeeded; in Wolińska-Brus's case, the link between the arrest warrant and the death sentence would have been hard to prove. How does one hold a judicial official who applied the law criminally liable for applying that law? ${ }^{122}$ The conclusion of the case is rather ironic: once again, the law failed the victims' as well as prosecutorial attempts to seek justice. But, as the legacy of the Fieldorf file also includes the fate of some twenty of his peers, its wider significance as a bridge between law and history, and between memory and truth during a time of remembering twentieth-century resistance fighters, should not be overlooked.

This article began by describing key features of Fieldorf's biography, namely his peculiar career path. Fieldorf's profile was then considered within the context of Soviet law, the Trial of the Sixteen, and the Polish legal model. The critical theme underpinning the Soviet model was the notion of Stalinist justice premised on legal objectives that were politicized to suit the regime's revolutionary goals. In this vein, the Trial of the Sixteen is important for two reasons: first, the west's refusal to speak out against the proceedings paved

z przesłością w Polsce i w Niemczech," in Albin Eser and Andrzej Zoll, eds., Prawo karne a problem zmiany ustroju politycznego / Strafrecht und politischer Systemweschel (Kraków, 1998), 19-72.

119. See IPN Sygn. Akt PO. Sl. 6/97, 1018-19.

120. It should be noted that the British War Crimes Act 1991 confers jurisdiction on British courts to try for war crimes committed in Nazi Germany or German-occupied territories during WWII persons who were not British citizens at the time but who have become British or naturalized citizens since that period.

121. Applebaum, "The Three Lives of Helena Brus."

122. See Kulesza, "Odpowiedzialność karna sędziów i prokuratorów," in Kulesza and Rzepliński, eds., Przestępstwa sędziów i prokuratorów. Wolińska-Brus had far-reaching authority and was responsible for following the orders transmitted by the Ministry of Public Security which resulted in allegations of torture and creating an atmosphere of terror. There are documents pointing to her political loyalty. See IPN 6/97, 2213-15. 
the way for Polish officials to use the law as a political weapon; and second, under the guidance of the Soviets, Polish authorities understood that the law and the legal profession had to undergo a complete overhaul to replace prewar Polish legal and historical narratives. The nature of Stalinist justice would become apparent when the close involvement of Soviet officials in legal education, judicial training, and the drafting of laws, as well as in the application of key decrees in Poland, was revealed. Archival material provides evidence for further analysis of the involvement of specific Polish judicial officials, particularly in the Fieldorf trial.

Polish narratives about the Stalinist period are not dissimilar to Czechoslovak ones. As Brad Abrams notes, the Czechoslovak narratives from this period reveal a politics of retribution. ${ }^{123}$ The Fieldorf case reveals political motives, legal maneuverings, and broader considerations surrounding the case and trial. The political strategy was characterized by the settling of accounts through the perversion of the law. In this way, three features of this trial are important for understanding the wider implications of the Fieldorf case. First, despite the fact that there were no staged trials of Polish communist leaders, there were many victims of Stalinist justice at the hands of those who worked behind the scenes. These collaborators, working in the Soviet secret police, were drafted to make sure that countries like Poland and Czechoslovakia accepted the Soviet version of communism. ${ }^{124}$ Second, judicial crimes were committed at a time when the international law community was discussing the misadministration of justice. Moreover, the judicial officials involved all had the requisite knowledge of the law to recognize that a crime was being committed. Two factors are telling: Polish officials in the hierarchy questioned the competence of certain judges, and legal education underwent reform early in the post-Stalinist era. Third, even during communist rule, legal and historical narratives about the case were not silenced. In fact, one of the most compelling narratives to dominate Polish legal discourse in the post-1989 period concerns the settling of accounts in judicial crimes. Ironically, although key elements of the crime have been set out, it is a concept that is very hard to defend in court. The matter was taken out of the prosecution's hands with the death of key perpetrators. Partial justice was achieved by confirming the identities of those who were involved in the decisions leading up to Fieldorf's execution, but the debate over the Fieldorf trial and its legacy will continue. ${ }^{125}$

123. Brad Abrams, “The Politics of Retribution: The Trial of Jozef Tiso," East European Politics and Societies 10, no. 2 (March 1996): 255-92. See also Jiří Pelikán, ed., The Czechoslovak Political Trials, 1950-1954: The Suppressed Report of the Dubček Government's Commission of Inquiry (Stanford, 1971), and Loebl, Sentenced and Tried.

124. See W. V. Wallace, review of Sentenced and Tried, by Eugene Loebl, Prague's 200 Days: The Struggle for Democracy in Czechoslovakia, by Harry Schwartz, The Czechoslovak Crisis 1968, ed. by Robert Rhodes James, and The Czech Black Book, ed. by Robert Littell, International Affairs 46, no. 1 (January 1970): 168-70.

125. The identities were revealed through the correspondence between judicial officials and the Fieldorf family, namely Maria Fieldorf, the general's daughter. See Fieldorf and Zachuta, Generat Fieldorf "Nil." 